attention. The Dunlop Estates carry a large proportion of clonal trees. Such trees give high yields, and their further development is a particular concern of the Research Centre, especially the relationship of latex quality, constitution and yield to the clonal strain. It is particularly opportune that the opening of the Research Centre in Malaya coincided with the opening of the Dunlop Research Centre in Birmingham (see Nature, July 8, p. 52). Many latex researches have necessarily to be carried out on the spot in the Far East ; but the close liaison with the research staff in Great Britain and periodical interchange of staff afford a unique opportunity of correlating quality after shipment with initial treatment and of bringing consumer and producer problems into true technical perspective. The new Malayan Research Centre keeps in close touch with the Rubber Research Institute in Kuala Lumpur, and there is much friendly co-opera. tion and rivalry with the technical groups of other producing companies in Malaya.

\section{New Material on Benjamin Franklin}

Besroes the story of "Philosophical Hall" which has served as the home of the Society for 160 years, a recent issue of the Proceedings of the American Philosophical Society (94, No. 3; June 20, 1950) contains a considerable amount of hitherto unpublished information about Benjamin Franklin. Among the papers is one by Prof. Gilbert Chinard describing the Abbé Lefebure de la Roche's recollections of Franklin; this is accompanied by a photograph of a portrait of Franklin painted by an unknown artist and acquired by the American Philosophical Society from Paris a year ago. Prof. I. B. Cohen comments on the facsimile of a short pamphlet printed by Franklin to describe his observations on the transit of Mercury which occurred in 1753. Franklin's anticipation of modern psychological warfare is reported by Lynam H. Butterfield in an article which describes the successful plan adopted jointly by Jefferson and Franklin to cause desertions among the Hessian mercenaries who had been hired by George III to take part in the American Civil War. The way Franklin's fame and influence increased in Italy until it reached a peak in the last half of the nineteenth century is described by Prof. Antonio Pace, while Charles Coleman Sellers gives an illustrated account of the portraits of Franklin painted by C. W. Peak. Among other interesting articles in the Proceedings is a description of some American students of "that shining oracle of physic", Dr. William Cullen of Edinburgh, during the years 1755-66, and the story of the magnetic recording of American Indian languages.

\section{Prehistory and the Humanities}

THE study of prehistory can be a pleasing intellectual hobby, dealing as it does with the origins and early cultures of mankind. But, while this is perhaps its main contribution to the present age there is, too, another more philosophical side to the picture. A realization of the great age not only of humanity but also of seemingly advanced cultures and their rise and fall does affect one's outlook on life. Our own times, seen against this vast background of antiquity, take on a new importance, or rather lack of importance. It is well, sometimes, for research workers in the field to stand back and look at the implications of their work. Dr. C. van Riet Lowe is clearly doing this in his article entitled "Prehistory and the Humanities" (S. African J. Sci.,
47,$3 ; 1950$ ), and finding something very interesting. One result of his studies which has impressed him has been the fact of the unity of the human race and the importance of the teaching of prehistory for demonstrating this fact. Dr. Lowe feels that an appreciation of spiritual issues is vital nowadays in our crumbling world, and that the churches would do well to realize and utilize the results obtained by what is already a long period of prehistoric research.

\section{Plant Viruses and Virus Diseases}

IN the Masters Memorial Lectures of the Royal Horticultural Society for 1949, delivered by $\mathrm{Dr}$. Kenneth M. Smith (J. Roy. Hort. Soc., 74, Pts. 11 and $12 ; 1949$ ), the whole subject of plant virus pathology is reviewed, and teachers will find them a very useful and well-illustrated summary of modern knowledge. With regard to the field of virus-insect relations, several new and useful points of view are expressed. Dr. Smith considers that the evidence for multiplication of the virus within an insect vector has not been, on the whole, very conclusive. He cites, however, the case of clover club-leaf virus, which retains infectivity over fifteen generations of its specific leaf-hopper vector. This would involve a dilution calculated at $10^{-17}$. No known virus appears to be able to sustain such a high dilution, and this discovery is perhaps the best piece of evidence that a virus can rultiply within its vector. It is also stated that, for non-persistent viruses, a short feeding time for an aphid of 3-5 minutes imparts maximum infectivity. Non-persistent viruses, indeed, seem to be carried only by aphids. Persistent viruses, on the other hand, may have leaf-hoppers, aphids and thrips as vectors.

\section{New Displays at the British Museum (Natural History)}

Is the July issue of the Museums Journal, Mr. J. P. Doncaster, who is in charge of the exhibition section at the British Museum (Natural History), describes some new displays of exhibits that have been installed recently. The classification of the vertebrates is the first subject dealt with, and here the aim is to present the basic facts required by the student of biology. To this end the existing wallcases were stripped of internal fittings and replaced by sloping display boards. Fluorescent tubes provide internal lighting. In general, the exhibited material is on the lower boards, while the upper are used for charts and diagrams. A neutral-grey fabric is used as a background, and labels are of two types. General and explanatory labels are given prominence by being printed on cream paper, while the individual labels for the specimens are printed on a grey paper which tones with the background. Another exhibit, on virus diseases, is also described. In conclusion, Mr. Doncaster deals with the systematic type of exhibit, especially in relation to mammals and birds. This pioneer article will be found to be of especial interest to all those engaged in modern museum display.

\section{Research Committee for the Gas Industry}

THE Gas Council announces that it has set up a research committee consisting of Sir Edgar Sylvester (chairman of the Gas Council); Sir Robert Robinson and Sir Cyril Hinshelwood (as two men of science not engaged in the gas industry); Mr. E. Crowther, Dr. R. S. Edwards, and Mr. W. K. Hutchison (members of the Gas Council); Mr. F. M. Birks (president of 